\title{
1 Improved nursery management further enhances the productivity of stress- tolerant rice varieties in coastal rainfed lowlands
}

3 Sukanta K. Sarangi ${ }^{1}$, Buddheswar Maji ${ }^{1}$, Sudhanshu Singh ${ }^{2}$, Dhiman Burman ${ }^{1}$, 4 Subhasis Mandal ${ }^{1}$, Dinesh K. Sharma ${ }^{3}$, U.S. Singh ${ }^{2}$, Abdelbagi M. Ismail ${ }^{4, *}$ and Stephan 5 M. Haefele ${ }^{5}$

$7 \quad{ }^{1}$ Central Soil Salinity Research Institute, Regional Research Station, Canning Town, India

$8 \quad{ }^{2}$ International Rice Research Institute, Delhi Office, India

$9 \quad{ }^{3}$ Central Soil Salinity Research Institute, Karnal, India

$10{ }^{4}$ International Rice Research Institute, Los Baños, Philippines

$11{ }^{5}$ Australian Centre for Plant Functional Genomics, University of Adelaide, Australia

*Corresponding author at: Crop and Environmental Sciences Division, International Rice Research

13 Institute, DAPO Box 7777, Metro Manila, Philippines. Tel.: +63 2580 5600; fax: +63 25805699

14 E-mail address: a.ismail@irri.org (A. M. Ismail).

\section{ABSTRACT}

The productivity of rice in most tropical coastal areas of Asia is low because of the predominance of several abiotic and biotic stresses, use of long duration traditional landraces or old varieties and suboptimal management practices. A combination of highyielding, stress-tolerant rice varieties and good management practices is necessary to

21 enhance the productivity of these areas. Suboptimal nursery management using traditional

22 methods practiced in these areas often leads to a reduced plant population because of

23 seedling mortality leading to poor yields. Nursery management practices that suit the new

24 stress-tolerant varieties recently becoming available need to be developed to increase the

25 productivity of rice. On-station and on-farm trials on nursery management were conducted

26 using improved rice varieties to study the effect of seed density, nutrient management in the 
27 nursery, and seedling age at transplanting on grain yield. Lower seed density and application

28 of balanced nutrients produced healthy and taller seedlings with high seedling vigour index

29 (SVI) in the nursery and with subsequent significant increase in grain yield after

30 transplanting in the main field. Combining inorganic and organic fertilizers in the seedbed

31 (50-30-15 kg N-P $\mathrm{O}_{5}-\mathrm{K}_{2} \mathrm{O} \mathrm{ha}{ }^{-1}+5 \mathrm{tha}^{-1}$ farm yard manures; FYM) enhanced seedling

32 growth (dry weight, shoot and root length, number of green leaves, leaf area) and leaf

33 nitrogen concentration. Forty-d-old seedlings produced significantly higher yield than 25-d-

34 old seedlings. Transplanting older seedlings is important in systems without good water

35 control, un-leveled fields, and soils affected by salt stress; and taller seedlings help avoid

36 losses caused by floods. The highest benefit/cost ratios of 1.82, 1.72 and 1.91 were observed

37 when transplanting 40-d-old seedlings using a seed density of $25 \mathrm{~g} \mathrm{~m}^{-2}$ and with balanced

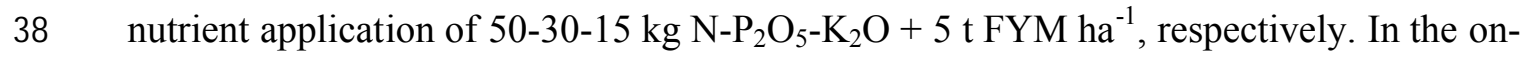

39 farm trials, the yield advantages when using new stress-tolerant rice varieties Swarna-Sub1

40 and Amal-Mana with improved nursery management practices were $23 \%$ and $47 \%$, in

41 comparison with farmers' nursery management and farmers' variety, respectively. These

42 cost-effective nursery management approaches have great potential for enhancing yield in

43 stress-prone rainfed coastal areas and will help sustain rice yield while ensuring

$44 \quad$ sustainability of the cropping system.

45

46 Keywords: Benefit/cost ratio; coastal zones; nursery management; rice varieties; stagnant

47 flooding; seedling age; seed density; seedling vigour; submergence-prone lowlands

49 1. Introduction

50 Coastal tropical deltas constitute a major rice production environment in south and

51 southeast Asia. However, they are often subject to flash floods or prolonged waterlogging 
52 caused by heavy monsoon rains in the wet season and the infrequent weather calamities

53 such as coastal storms and cyclones, causing serious floods and salt intrusion (Ismail and

54 Tuong, 2009). Soils in these areas are saline during the dry season and at the beginning of

55 the wet season. Combined with poor surface and subsurface drainage, these conditions limit

56 the choices of crops and the use of improved varieties.

57 One example of such system is the Sundarban area of the lower Gangetic delta,

58 located in the eastern part of India and southern Bangladesh. Rice is the major crop in this

59 delta, occupying about $98 \%$ of the cultivated area under rainfed conditions during the wet

60 season (monsoon/kharif; June to December). Growing other crops is difficult during this

61 period because of flooding caused by heavy rain. The productivity of rice is low $\left(<2 \mathrm{tha}^{-1}\right)$

62 due to common biotic and abiotic stresses, preferred use of long-duration traditional

63 landraces or old varieties, and suboptimal agronomic practices in the nursery and the main

64 field. Besides submergence and stagnant flooding, rice production in these coastal deltas is

65 also challenged by other factors, including nutrient limitations, salinity, drought, and pests

66 and diseases (Ismail and Tuong, 2009). Thus, a combination of high-yielding, stress-tolerant

67 varieties and good management practices is necessary to boost current productivity levels.

68 A widespread constraint for rice production in the delta is the incidence of complete

69 submergence for 1-2 weeks and/or stagnant floods (SF, 25-50 cm) for most of the season

70 caused by excessive rain or overflowing rivers, resulting in severe damage to rice (Das,

71 2012). Farmers' current varieties are not adapted to such conditions and their yields are

72 severely reduced because of high mortality, suppressed tillering, reduced panicle size, and

73 high sterility (Wassmann et al., 2009). However, recently released varieties in India, which

74 are submergence-tolerant (contain the SUB1 gene; e.g., Swarna-Sub1), can substantially

75 increase rice productivity in such flood-affected areas (Singh et al., 2009; Mackill et al.,

76 2012; Ismail et al., 2013; Singh et al., 2014). Sub1 rice genotypes slow down their growth 
77 when inundated, resulting in their survival and fast recovery when floodwaters recede. Other

78 genotypes, such as Amal-Mana, elongate when flooded, making them more suited to areas

79 where shallower floodwater stagnates in the field for several weeks or months (Singh et al.,

80 2011; Sarkar and Bhattacharjee 2012; Vergara et al., 2014; Kato et al. 2014). The yield

81 advantage of these stress-tolerant varieties is greater when exposed to stresses and in most

82 cases; they produce higher yields over older varieties in the absence of stress (Singh et al.

83 2009, Singh et al. 2013, Ismail et al. 2013, Singh et al, 2014)

84 The general management recommendations of rice nursery for favorable conditions

85 are well established, usually involve seeding density of 50-100 $\mathrm{g} \mathrm{m}^{-2}$, nutrient application

86 through inorganic as well as organic sources and transplanting younger seedling (Rice

87 Knowledge Bank; http://www.knowledgebank.irri.org). However, these recommendations

88 need to be validated for less favorable areas where growing conditions are mostly different.

89 Generally, crop establishment is a major constraint to productivity in all areas affected by

90 early incidences of abiotic stresses, such as drought, flooding, and salinity, because seedlings

91 are very sensitive to these stresses. An adaptive management strategy is the use of healthy

92 seedlings grown in properly managed nurseries to ensure good crop stand. Practices such as

93 optimum seeding density, proper seedling age, careful handling at transplanting, and balanced

94 nutrient supply, were reported to help mitigate the adverse effects of floods and other abiotic

95 stresses following transplanting (Ram et al., 2009; Ella and Ismail, 2006; Ella et al., 2011;

96 Ismail et al., 2012; Sumon et al., 2013; Gautam et al., 2014; Bhowmick et al., 2014),

97 however, the effectiveness of these practices have not been sufficiently validated for saline

98 coastal areas. Integration of locally available organic sources of nutrients such as farmyard

99 manure (FYM) with fertilizer recommendations was reported to be effective for rice in

100 coastal areas (Sarangi et al., 2014). Use of healthy seedlings could improve the productivity

101 of transplanted rice in saline coastal zones as high salinity stress retards elongation of 
transplanted seedlings and reduces nutrient availability during early growth. Age of seedlings

103 at transplanting is particularly important for areas affected by salinity and floods because

104 younger seedlings are more sensitive to both stresses. Results from drought stress affected

105 areas in the mid-hills of Nepal highlighted the importance of good seedbed management and

106 right seedling age, leading to significantly higher rice yields (Adhikari et al., 2013).

107 The present study was conducted to examine the effect of seed density, seedling age,

108 and nursery nutrient management on seedling health, crop establishment and grain yield. We

109 hypothesize that combining good nursery practices with tolerant varieties will enhance crop

110 establishment and yield in these less favorable areas. The best nursery management options

111 developed in on-station trials were subsequently validated over two successive years in

112 farmers' fields with new stress-tolerant rice varieties.

113

114 2. Materials and methods

115 The studies were conducted at the Central Soil Salinity Research Institute Regional

116 Station (CSSRI-RRS) at Canning Town $\left(22^{\circ} 15^{\prime} \mathrm{N}, 88^{\circ} 40^{\prime} \mathrm{E} ; 3.0 \mathrm{~m}\right.$ above MSL) during the

117 wet seasons of 2011 and 2012 (on-station) and in farmers' fields during the wet seasons of

1182012 and 2013 (Table 1). The on-farm trials were conducted at eight locations spreading

119 across two districts (North and South 24 Parganas) of West Bengal, India (Table 2). The soil

120 in the station is heavy textured, with $40-43 \%$ clay, $10 \%$ sand, and $47-50 \%$ silt. The $\mathrm{pH}$ of the

121 top soil varied from 5.8 to 7.1 , with average bulk density of 1.49 and organic carbon

122 concentration of $0.48 \%$. The experimental area was mono-cropped with rice for the last three

123 years preceding the trials.

\section{Table 1}

125 Details of field experiments conducted at CSSRI-RRS Canning Town (on-station) and at 126 farmers' fields (on-farm) during the wet seasons of 2011-2013. 


\section{Experiment and Treatments Details}

design

On-station experiment (wet seasons of 2011 and 2012)

Experiment $1 \quad$ Main-plot: Seedling age (T)

T1: 40 days (d), T2: $25 \mathrm{~d}$;

Nursery management Sub-plot: Seed density (D)

D1: $40 \mathrm{~g} \mathrm{~m}^{-2}, \mathrm{D} 2: 25 \mathrm{~g} \mathrm{~m}^{-2}$;

Sub-sub plot: Nutrient

Management (N)

N1: 25-0-0, N2: 50-30-15, N3: 25-30-15, N4: 0$30-15 \mathrm{~kg} \mathrm{~N}-\mathrm{P}_{2} \mathrm{O}_{5}-\mathrm{K}_{2} \mathrm{O} \mathrm{ha}^{-1}$; FYM at $5 \mathrm{t} \mathrm{ha}^{-1}$ was applied uniformly to all plots.

On-farm experiment (wet seasons of 2012 and 2013)

Experiment $2 \quad$ Farmer's method of nursery

Nursery management management using local RBD

Farmer's nursery management with improved variety

Improved nursery management with improved variety

High seed density $\left(>75 \mathrm{~g} \mathrm{~m}^{-2}\right)$; fertilizer at $25-0-0$ kg N- $\mathrm{P}_{2} \mathrm{O}_{5}-\mathrm{K}_{2} \mathrm{O}$ ha ${ }^{-1}$; seedling age: $25-30-\mathrm{d}$; varieties: Pratikshya, Pankaj, Mahsuri, Sabita and CR1017;

As above except using Amal-Mana and Swarna-

Sub1;

Seed density: $25 \mathrm{~g} \mathrm{~m}^{-2}$; fertilizer at $50-30-15 \mathrm{~kg}$ $\mathrm{N}-\mathrm{P}_{2} \mathrm{O}_{5}-\mathrm{K}_{2} \mathrm{O}+5$ t FYM ha ${ }^{-1}$; seedling age: $40-\mathrm{d}$; varieties: Amal-Mana and Swarna-Sub1

Table 2

Details of locations, varieties, and plot sizes of on-farm trials conducted during 2012 and

\begin{tabular}{|c|c|c|c|c|c|c|}
\hline Farmer* & Longitude & Latitude & Village & $\begin{array}{c}\text { Improved } \\
\text { variety }\end{array}$ & $\begin{array}{c}\text { Farmer's } \\
\text { variety }\end{array}$ & $\begin{array}{c}\text { Plot size } \\
\left(\mathbf{m}^{2}\right)\end{array}$ \\
\hline
\end{tabular}

\begin{tabular}{lllllll}
\hline \multicolumn{4}{l}{ District: South 24 Parganas } & & & \\
F1 & $88^{\circ} 49^{\prime} 5^{\prime \prime} \mathrm{E}$ & $22^{\circ} 8^{\prime} 9^{\prime \prime} \mathrm{N}$ & Dulki & Swarna-Sub1 & Pratikshya & 295 \\
F2 & $88^{\circ} 49^{\prime} 10^{\prime \prime} \mathrm{E}$ & $22^{\circ} 8^{\prime} 12^{\prime \prime} \mathrm{N}$ & Pakhiralay & Amal-Mana & CR 1017 & 140 \\
F3 & $88^{\circ} 49^{\prime} 8^{\prime \prime} \mathrm{E}$ & $22^{\circ} 8^{\prime} 14^{\prime \prime} \mathrm{N}$ & Pakhiralay & Swarna-Sub1 & Pratikshya & 238 \\
F4 & $88^{\circ} 49^{\prime} 13^{\prime \prime} \mathrm{E}$ & $22^{\circ} 8^{\prime} 17^{\prime \prime} \mathrm{N}$ & Pakhiralay & Amal-Mana & Pankaj & 275
\end{tabular}

\section{District: North 24 Parganas}

\begin{tabular}{lllllll} 
F5 & $88^{\circ} 49^{\prime} 12^{\prime \prime} \mathrm{E}$ & $22^{\circ} 23^{\prime} 51^{\prime \prime} \mathrm{N}$ & Simulhati & Amal-Mana & Mahsuri & 352 \\
F6 & $88^{\circ} 49^{\prime} 26^{\prime \prime} \mathrm{E}$ & $22^{\circ} 23^{\prime} 48^{\prime \prime} \mathrm{N}$ & Simulhati & Amal-Mana & Mahsuri & 135 \\
F7 & $88^{\circ} 49^{\prime} 21^{\prime \prime} \mathrm{E}$ & $22^{\circ} 23^{\prime} 47^{\prime \prime} \mathrm{N}$ & Simulhati & Swarna-Sub1 & Sabita & 252 \\
F8 & $88^{\circ} 49^{\prime} 16^{\prime \prime} \mathrm{E}$ & $22^{\circ} 23^{\prime} 50^{\prime \prime} \mathrm{N}$ & Simulhati & Amal-Mana & Pankaj & 110 \\
\hline
\end{tabular}


137 The climate at the site is tropical monsoon with an average annual rainfall of $1,802 \mathrm{~mm}$, of 138 which about $89 \%$ occurs in the monsoon season (June-October). Total seasonal rainfall was $1391,704,1,361$, and 1,936 $\mathrm{mm}$ for 2011, 2012, and 2013, respectively. Overall, the rainfall was 140 well distributed during seasons and little rain was experienced during the maturity period

141 (November and December). Maximum temperature varied between 25.6 to $33.3{ }^{\circ} \mathrm{C}, 25.2$ to

$14235.1{ }^{\circ} \mathrm{C}$, and 26.9 to $33.3{ }^{\circ} \mathrm{C}$ during 2011,2012 , and 2013, respectively. Minimum

143 temperature was lowest in December $\left(14.6,13.7\right.$, and $\left.14.5^{\circ} \mathrm{C}\right)$ and highest in June $(26.4,27.6$, 144 and $26.6^{\circ} \mathrm{C}$ ) during the three respective years.

\subsection{On-station trials}

147 On-station experiments were conducted in a split-split-plot design using rice variety Amal-Mana (Table 1). Top-soil salinity ( $\mathrm{EC}_{\mathrm{e}}$; electrical conductivity of saturated soil extract in the top $20 \mathrm{~cm}$ ) was between 4.0-5.0 dS m $\mathrm{m}^{-1}$. The treatments used seedlings from two seed densities (D1: 40 and D2: $25 \mathrm{~g} \mathrm{~m}^{-2}$ ) for the sub-plots, two seedling ages at planting (T1: 40-dand T2: $25-\mathrm{d})$ for the main plots, and four nutrient combinations of $\mathrm{N}-\mathrm{P}_{2} \mathrm{O}_{5}-\mathrm{K}_{2} \mathrm{O} \mathrm{kg} \mathrm{ha}{ }^{-1}\left(\mathrm{~N}_{1}\right.$ : 25-0-0, $\mathrm{N}_{2}: 50-30-15, \mathrm{~N}_{3}: 25-30-15$, and $\mathrm{N}_{4}: 0-30-15$ ) for the sub-sub-plots. Treatment $\mathrm{N}_{1}$ represented farmer's practice of applying only some urea and FYM in nursery. In all plots, $5 \mathrm{t}$ $\mathrm{ha}^{-1}$ of FYM were applied as basal. Sowing in the seedbed was staggered at 15 -d intervals so that transplanting could be done on the same day. The full dose of phosphorus and potassium and $50 \%$ of nitrogen were applied as basal at sowing based on respective treatments. The rest

157 of the nitrogen was applied in two equal splits at $15 \mathrm{~d}$ of sowing and $7 \mathrm{~d}$ before uprooting.

158 The seedlings were transplanted on 1 August using 2 seedlings hill ${ }^{-1}$ at spacing of $15 \times 15 \mathrm{~cm}$.

159 All plots in the field received similar treatments, including FYM at $5 \mathrm{t} \mathrm{ha}^{-1}$ applied one month 160 before transplanting and inorganic fertilizers at 50-20-10 kg N-P $\mathrm{O}_{5}-\mathrm{K}_{2} \mathrm{O}$ ha ${ }^{-1}$. P and $\mathrm{K}$ were 
applied as basal before transplanting, whereas nitrogen in the form of urea was applied in

162 three equal splits at $7 \mathrm{~d}$ after transplanting (DAT), at maximum tillering (45 DAT), and at 163 initiation of flowering (75 DAT).

164 Growth measurements were made on ten randomly sampled seedlings from each 165 treatment in the nursery at one week (1w), two weeks (2w) after sowing, and at transplanting 166 time (25 and $40 \mathrm{~d}$ after sowing based on respective treatments). Number and area of green 167 leaves per seedling were recorded on five seedlings from each plot. Nitrogen concentrations 168 in leaves were determined following digestion in concentrated $\mathrm{H}_{2} \mathrm{SO}_{4}$ at $400{ }^{\circ} \mathrm{C}$ (Varley, 169 1966). The seedling vigour index (SVI) for different treatments was calculated at the time of 170 uprooting using the formula: SVI = seedling length (total shoot and root length) $\times \%$

171 germination, based on Abdul-Baki and Anderson (1973). Germination percentage was

172 determined in a petri dish using 1,000 seeds from each seed stock used in the experiment.

173 Total shoot and root lengths were measured for seedling length to calculate SVI. In coastal 174 areas, higher shoot length is necessary for survival when transplanting in flooded fields and 175 robust root helps in quick recovery after submergence.

176 Seedlings from all treatments and replications were uprooted separately and 177 transplanted in the main field following uniform management practices. Twelve hills from 178 each plot were randomly sampled at harvest to determine yield attributes. To determine the 179 panicle number per hill, only the panicle-bearing tillers were counted and averaged over 12 180 hills. Panicles were hand-threshed, filled (grains) and empty spikelets (chaff) were separated 181 by submerging threshed spikelets in tap water and the number of grains per panicle was 182 counted and averaged over 12 hills. All floating spikelets were considered empty. After 183 thoroughly drying the grains under the sun, 1,000-grain weight was recorded for each 184 treatment. From each net plot area of $20 \mathrm{~m}^{2}$, grains were harvested, dried, and weighed, and 185 grain weight was adjusted to moisture content of $0.14 \mathrm{~g} \mathrm{H}_{2} \mathrm{O} \mathrm{g}^{-1}$ fresh weight. 
187 The objective of this study was to validate the improved nursery management practices 188 identified on-station together with improved rice varieties (Amal-Mana and Swarna-Sub1) in 189 natural farmers' fields. The farmers were selected in the target area based on land type and 190 water depth suitable for each of the improved varieties. For Amal-Mana, five farmers having 191 lowlands with usual standing water depth of 30-40 $\mathrm{cm}$ for most of the monsoon season 192 (stagnant flood, SF) were selected, whereas, for Swarna-Sub1, only three farmers were 193 chosen (Table 2), with lands of medium elevation and usually with $15-25 \mathrm{~cm}$ of standing 194 water but regular flash floods (water depth exceeds $30 \mathrm{~cm}$ during this period, completely 195 inundating the plants but for only a short duration) after transplanting, which adversely affects crop establishment (Fig. 1). During 2012, Amal-Mana experienced maximum 197 submergence during early tillering, while Swarna-Sub1 experienced flash flood at active 198 tillering stage. In 2013, Swarna-Sub1 was inundated during late tillering, whereas Amal199 Mana experienced the deepest stagnant flooding both during active tillering and panicle 200 initiation (Fig. 1).

(a)

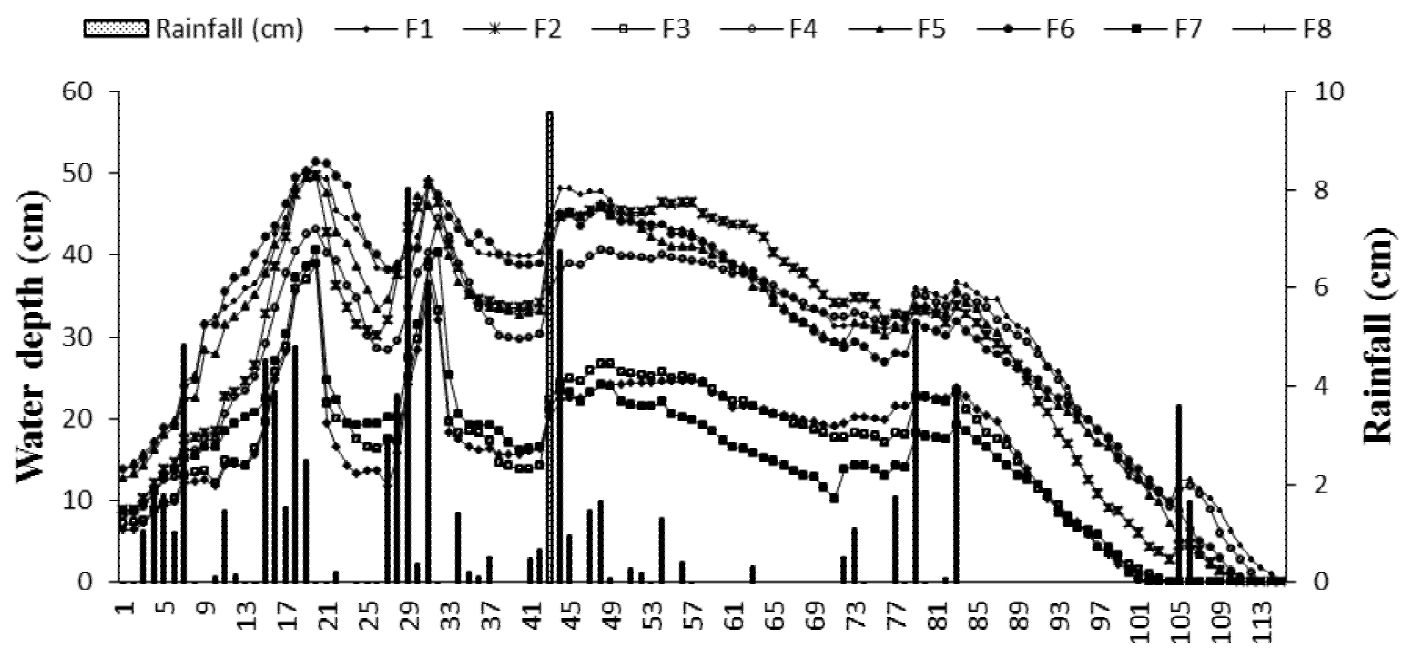

Days after transplanting 
(b)

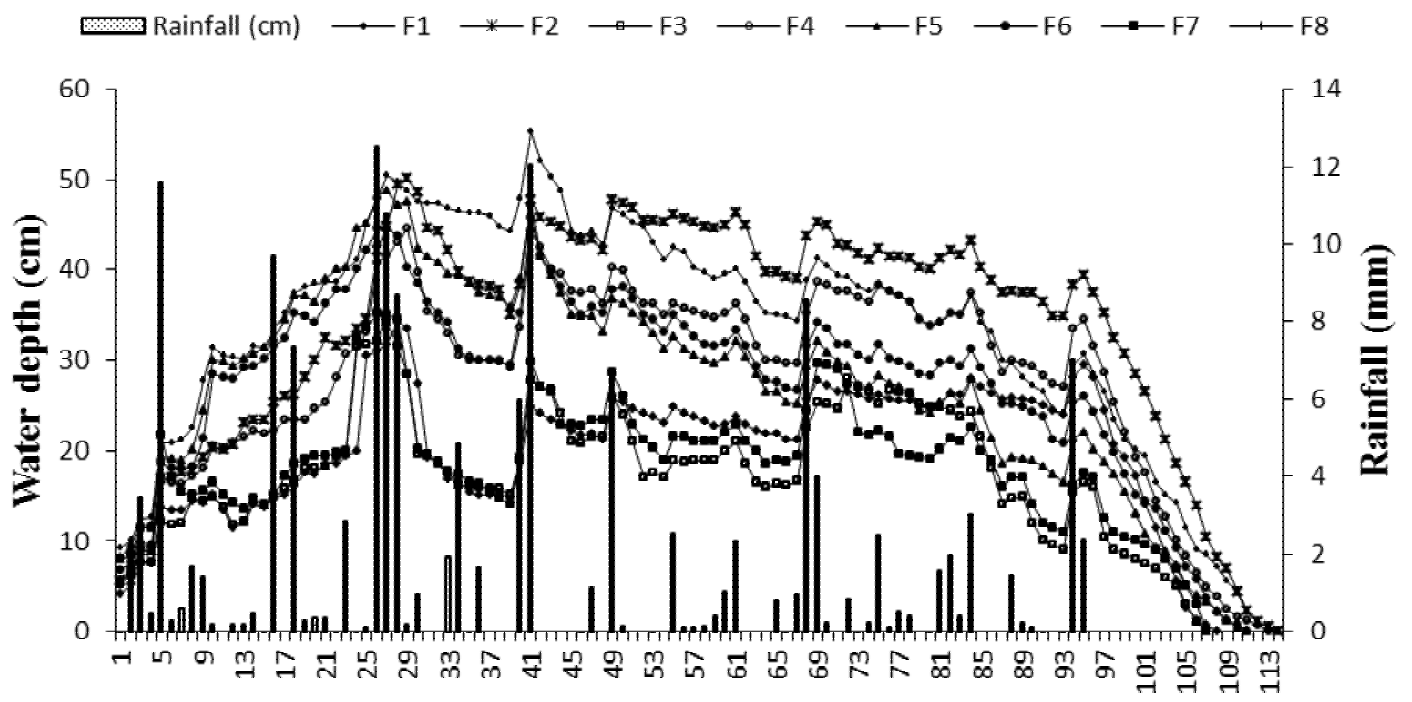

Days after transplanting

203

204

205

206

207

208

209

210

211

212

213

214

215

216

217

218

219
Each on-farm experiment was laid as a randomized block design (RBD) with six replications and three treatments - T1: farmer's nursery management (NM) with farmer's varieties (Table 2); T2: farmer's NM with improved varieties (Amal-Mana or Swarna-Sub1); and T3: improved NM with improved variety (Table 1). The varieties traditionally grown by farmers were mostly released during the 1980's except Pratikshya, which was released in 2005. The improved varieties recently developed for coastal lowland areas were released in 2008 (Amal-Mana) and 2009 (Swarna-Sub1) (Ismail et al., 2013). The improved nursery management practices using a seed density of $25 \mathrm{~g} \mathrm{~m}^{-2}, 40$-d-old seedlings at transplanting,

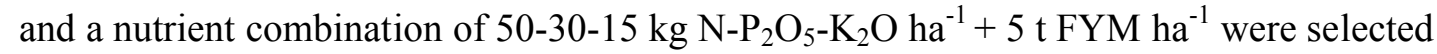
based on data from on-station trials. In all locations, the soil was initially saline (ECe of 4.02 to $4.79 \mathrm{dS} \mathrm{m}^{-1}$ ) and slightly acidic (pH of 5.04 to 6.28 ). Nurseries were sown using certified seeds in mid-June and seedlings were transplanted in the last week of July using two 
seedlings per hill spaced at $15 \times 15 \mathrm{~cm}$. Fertilizers were applied at 50-20-10 kg N-P $\mathrm{O}_{5}-\mathrm{K}_{2} \mathrm{O}$

$221+5$ t FYM ha $^{-1}$ uniformly in all farmers' fields during both years. The depth of water in the

222 field (Fig. 1) was monitored using a meter stick installed in each plot. SVI, grain and straw

223 yields were recorded following the methods used in on-station trials.

224

225

\subsection{Statistical and economic analyses}

The data were subjected to analysis of variance (Gomez and Gomez, 1984) using the

MSTAT statistical package. Treatment means of on-station experiments were separated using

least significant difference (LSD) tests and compared at $p<0.05$ level of significance. The

interactions of factors monitored in this study were found to be non-significant and were not

reported. Mean data over the two years of study are presented for all parameters as no

significant interactions were observed between treatments and years. The variety-wise means

of the 3 combinations of treatments across two seasons were compared separately using the least

significant difference $(\mathrm{LSD})$ tests at $P \leq 0.05$. Each treatment value, therefore, represents a mean of

36 data points for trials using Swarna-Sub1 (3 on-farm trials with 6 replications in each trial) and 60 data point for trials using Amal-M ana (5 on-farm trials with 6 replications in each trial).

Economic evaluation of different treatments was based on total variable cost, gross return, gross margin, and benefit/cost ratio (BCR). Total variable cost included the costs of inputs (seed, fertilizer, and pesticides); labour (for land preparation, irrigation, fertilizer and pesticide application, harvesting, bundling, hauling, and threshing), and renting a power tiller

240 for land preparation and a pump for irrigation. Gross returns were calculated by multiplying

241 the amount of produce (grain and straw) by its corresponding price at harvest. The gross

242 margin was computed by subtracting total variable costs from gross returns, and BCR was

243 calculated by dividing gross returns by total variable costs. The economic analysis uses

244 prevailing market prices of inputs, labour, and produce during 2013-14 in Indian Rupees

245 (INR, ₹), which was then converted into US\$ using the conversion rate $\$ 1=₹ 60$. 


\section{Results}

3.1. On-station trials for evaluation of nursery management practices

The dry weight of seedlings increased with age (Table 3) and it was highest at uprooting for 40 -d-old seedlings (7.4 g per 10 seedlings ). Seedling biomass was $91 \%$ higher under the low seed density of $25 \mathrm{~g} \mathrm{~m}^{-2}$ compared with that of the higher seed density of $40 \mathrm{~g}$ $\mathrm{m}^{-2}$. Among the nutrient levels, the highest dry weight of seedlings was observed with $50-30-$ $15 \mathrm{~kg} \mathrm{~N}-\mathrm{P}_{2} \mathrm{O}_{5}-\mathrm{K}_{2} \mathrm{O}+5 \mathrm{t}$ FYM ha ${ }^{-1}$ applied to the nursery. The dry weight per 10 seedlings was more than $100 \%$ higher with the $50-30-15 \mathrm{~kg} \mathrm{~N}-\mathrm{P}_{2} \mathrm{O}_{5}-\mathrm{K}_{2} \mathrm{O}+5$ t FYM ha ${ }^{-1}$ treatment compared with the 25-0-0 kg N-P $\mathrm{O}_{5}-\mathrm{K}_{2} \mathrm{O}+5 \mathrm{t} \mathrm{FYM} \mathrm{ha}^{-1}$.

Shoot length, root length, number of green leaves and leaf area per seedling were significantly higher in 40-d-old seedlings (Table 3). Average seedling shoot length was 46 and $63 \mathrm{~cm}$ for $25-$ and $40-d-o l d ~ s e e d l i n g s$, respectively. Seedling root was $27 \%$ longer in $40-$ d- than in 25 -d-old seedlings. Older ( $40 \mathrm{~d}$ ) seedlings had more than 4 green leaves, whereas the 25-d-old seedlings had less than 4 leaves per seedling. Seedling shoot length, root length, number of green leaves, leaf area per seedling and leaf $\mathrm{N}$ concentration were higher with

262 lower nursery seed rate $\left(25 \mathrm{~g} \mathrm{~m}^{-2}\right)$. The seedlings' leaf $\mathrm{N}$ concentration increased by $7.3 \%$ at 263 seeding density of $25 \mathrm{~g} \mathrm{~m}^{-2}$ compared with that at $40 \mathrm{~g} \mathrm{~m}^{-2}$. The treatment combining $5 \mathrm{tha}^{-1}$ 264 FYM with 50-30-15 kg N-P $\mathrm{O}_{5}-\mathrm{K}_{2} \mathrm{O}$ ha ${ }^{-1}$ in nursery improved shoot length, root length, 265 number of green leaves, and leaf area per seedling and resulted in significantly higher leaf $\mathrm{N}$ 266 concentration (1.93) than the other nursery nutrient treatments. 


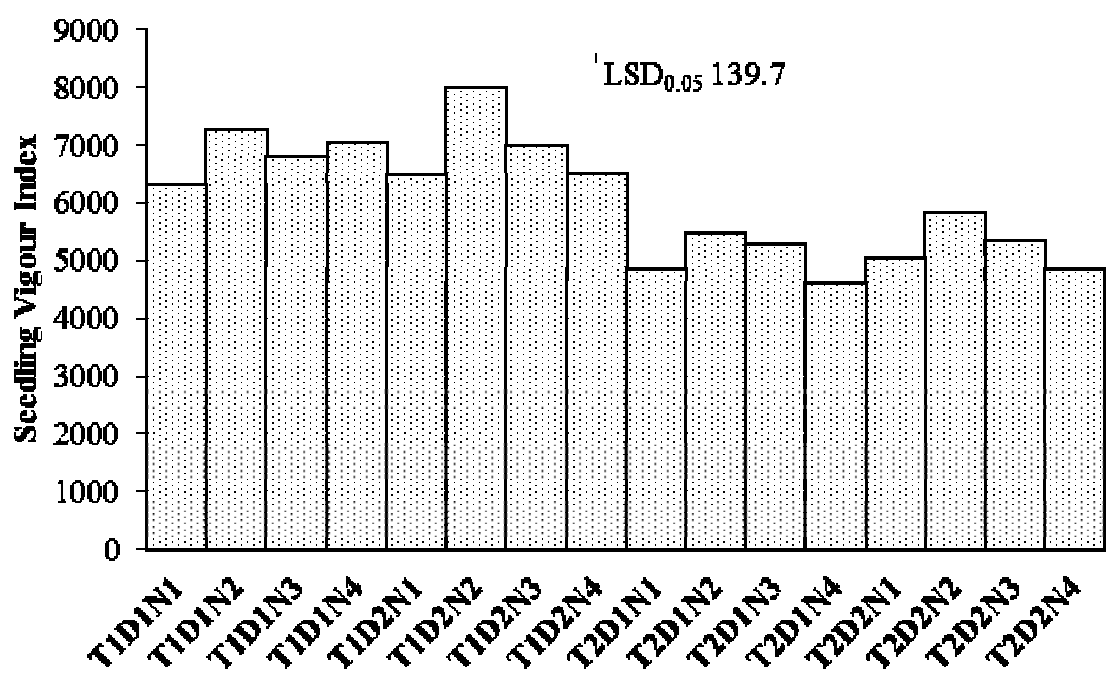

269 Fig. 2. Seedling vigour index under different combinations of nursery management practices

270 in the on-station experiment at CSSRI-RRS, Canning Town, West Bengal, India. Data are

271 means of the wet seasons of 2011 and 2012. Vertical bars indicate LSD at $P \leq 0.05$ for

272 treatment means.

273 [T: Seedling age $(\mathrm{T} 1=40-\mathrm{d}, \mathrm{T} 2=25-\mathrm{d}), \mathrm{D}$ : seeding rate $\left(\mathrm{D} 1=40 \mathrm{~g} \mathrm{~m}^{-2}, \mathrm{D} 2=25 \mathrm{~g} \mathrm{~m}^{-2}\right), \mathrm{N}$ :

274 nutrient management $\left(\mathrm{N}_{1}=25-0-0, \mathrm{~N}_{2}=50-30-15, \mathrm{~N}_{3}=25-30-15\right.$ and $\mathrm{N}_{4}=0-30-15 \mathrm{~kg} \mathrm{~N}-$

$275 \mathrm{P}_{2} \mathrm{O}_{5}-\mathrm{K}_{2} \mathrm{O}$ ha $^{-1}$; in all plots, $5 \mathrm{tha}^{-1} \mathrm{FYM}$ were applied as basal)]

276

277 SVI (Fig. 2) was highest (7,998) with the combination of 40-d-old seedlings (T1), $25 \mathrm{~g} \mathrm{~m}^{-2}$

278 seed rate (D2), and nutrient application of 50-30-15 $\mathrm{kg} \mathrm{N}-\mathrm{P}_{2} \mathrm{O}_{5}-\mathrm{K}_{2} \mathrm{O}$ ha ${ }^{-1}$ with $5 \mathrm{t} \mathrm{ha}^{-1} \mathrm{FYM}$

279 (N2); and lowest $(4,595)$ for 25-d-old seedlings (T2), $40 \mathrm{~g} \mathrm{~m}^{-2}$ seed rate (D1), and 0-30-15 $\mathrm{kg}$

$280 \mathrm{~N}-\mathrm{P}_{2} \mathrm{O}_{5}-\mathrm{K}_{2} \mathrm{O}$ ha $^{-1}(\mathrm{~N} 4)$.

281

282

Table 3

283 Effects of nursery management practices on seedling growth in the nurser, in the on-station 284 experiment at CSSRI-RRS, Canning Town. Shoot length, root length, number of green 
285 leaves, leaf area and leaf $\mathrm{N}$ concentration were determined when plats were uprooted for 286 transplantation. Data are mean of 2011 and 2012 wet seasons.

287

\begin{tabular}{|c|c|c|c|c|c|c|c|c|}
\hline & \multicolumn{3}{|c|}{ Dry weight (g 10 seedlings $\left.^{-1}\right)^{\S}$} & \multirow{2}{*}{$\begin{array}{c}\text { Shoot } \\
\text { Length } \\
\text { (cm) }\end{array}$} & \multirow{2}{*}{$\begin{array}{l}\text { Root } \\
\text { length } \\
(\mathrm{cm})\end{array}$} & \multirow{2}{*}{$\begin{array}{c}\text { No. of green } \\
\text { leaves } \\
\text { seedling }^{-1}\end{array}$} & \multirow{2}{*}{$\begin{array}{l}\text { Leaf area } \\
\quad\left(\mathrm{cm}^{2}\right. \\
\left.\text { seedling }^{-1}\right)\end{array}$} & \multirow{2}{*}{$\begin{array}{c}\text { Leaf } \mathbf{N} \\
\text { concentr } \\
\text { ation } \\
(\%)\end{array}$} \\
\hline & $1^{\text {st }} \mathbf{w k}$ & $2^{\text {nd }} \mathbf{w k}$ & $\begin{array}{c}\text { Up- } \\
\text { rooting }\end{array}$ & & & & & \\
\hline \multicolumn{9}{|c|}{ Seedling age } \\
\hline $40-d$ & 0.45 & 0.79 & 7.74 & 62.6 & 16.1 & 4.4 & 41.9 & 1.55 \\
\hline $25-d$ & 0.46 & 0.70 & 3.30 & 45.9 & 12.7 & 3.9 & 39.0 & 1.56 \\
\hline $\operatorname{LSD}_{0.05}$ & $\mathrm{~ns}^{a}$ & 0.09 & 0.29 & 1.0 & 0.6 & 0.4 & 1.4 & Ns \\
\hline \multicolumn{9}{|c|}{ Seeding rate } \\
\hline $40 \mathrm{~g} \mathrm{~m}^{-2}$ & 0.41 & 0.69 & 3.79 & 53.3 & 13.9 & 3.8 & 33.8 & 1.50 \\
\hline $25 \mathrm{~g} \mathrm{~m}^{-2}$ & 0.50 & 0.80 & 7.25 & 55.2 & 14.9 & 4.4 & 47.0 & 1.61 \\
\hline $\operatorname{LSD}_{0.05}$ & 0.04 & 0.02 & 0.31 & 1.1 & 0.5 & 0.1 & 1.1 & 0.02 \\
\hline \multicolumn{9}{|c|}{ Nutrient management $\left(\mathrm{kg} \mathrm{N}-\mathrm{P}_{2} \mathrm{O}_{5}-\mathrm{K}_{2} \mathrm{O} \mathrm{ha}^{-1}+5 \mathrm{tha}^{-1} \mathrm{FYM}\right)$} \\
\hline $25-0-0$ & 0.41 & 0.74 & 4.46 & 51.3 & 13.1 & 4.1 & 32.4 & 1.36 \\
\hline $50-30-15$ & 0.56 & 0.81 & 9.19 & 60.0 & 15.5 & 5.2 & 58.7 & 1.93 \\
\hline $25-30-15$ & 0.44 & 0.83 & 4.48 & 54.6 & 14.7 & 3.7 & 37.8 & 1.59 \\
\hline $0-30-15$ & 0.42 & 0.61 & 3.96 & 51.0 & 14.3 & 3.5 & 32.8 & 1.35 \\
\hline $\operatorname{LSD}_{0.05}$ & 0.03 & 0.05 & 0.46 & 1.46 & 0.5 & 0.3 & 1.4 & 0.02 \\
\hline
\end{tabular}
ns $=$ not significant

$\S_{1 \mathrm{wk}, 2} \mathrm{wk}$, and uprooting are observations at one week, two weeks, and at time of uprooting for the nursery for transplanting, respectively.

Nursery management options had a significant effect on yield and yield attributes except for 1,000-grain weight (Table 4). However, all interactions of seed rate, nutrient options, and seedling age were not significant for yield attributes and grain and straw yields. The number of tillers hill ${ }^{-1}$ and panicles hill ${ }^{-1}$ were significantly higher when transplanting 40d-old seedlings than 25 -d-old seedling. Low density seeding produced $6 \%$ more tillers and panicles per hill than high density seeding. The number of tillers and panicles per hill also increased significantly with the application of 50-30-15 $\mathrm{kg} \mathrm{N}-\mathrm{P}_{2} \mathrm{O}_{5}-\mathrm{K}_{2} \mathrm{O} \mathrm{ha}^{-1}+5 \mathrm{t} \mathrm{FYM} \mathrm{ha}{ }^{-1}$ in nursery than with other nutrient treatments. Increase in panicles hill ${ }^{-1}$ is mainly due to commensurate increase in tillers hill ${ }^{-1}$. Grains per panicle increased by about $3 \%$ at lower 
301

302

303

304

305

306

307

308

309

310

nursery seeding rate over the high rate. Similar effects were also observed with transplanting 40-d-old seedlings compared with 25-d-old seedlings. The number of grains per panicle was lowest in the treatment involving no or low nitrogen, but increased significantly when nitrogen application was increased from 0 to $50 \mathrm{~kg} \mathrm{ha}^{-1}$ with similar $\mathrm{P}$ and $\mathrm{K}$.

\section{Table 4}

Grain yield and yield components of variety Amal-Mana as affected by nursery management in on-station experiment at CSSRI-RRS, Canning Town. Data are means of 2011 and 2012 wet seasons.

\begin{tabular}{|c|c|c|c|c|c|c|}
\hline & $\begin{array}{c}\text { Tillers } \\
\text { hill }^{-1}\end{array}$ & $\begin{array}{c}\text { Panicles } \\
\text { hill }^{-1}\end{array}$ & $\begin{array}{c}\text { Grains } \\
\text { panicle }^{-1}\end{array}$ & $\begin{array}{l}1000 \text { grain } \\
\text { weight (g) }\end{array}$ & $\begin{array}{c}\text { Grain yield } \\
\left(t \text { ha }^{-1}\right)\end{array}$ & $\begin{array}{c}\text { Straw yield } \\
\left(\mathbf{t} \mathbf{h a}^{-1}\right)\end{array}$ \\
\hline \multicolumn{7}{|c|}{ Age of seedlings } \\
\hline $40-d$ & 11.5 & 9.7 & 121.5 & 29.9 & 4.27 & 7.83 \\
\hline $25-d$ & 9.7 & 8.3 & 118.8 & 29.8 & 3.50 & 7.11 \\
\hline $\operatorname{LSD}_{0.05}$ & 0.4 & 0.4 & 1.4 & $\mathrm{~ns}^{*}$ & 0.35 & 0.34 \\
\hline
\end{tabular}

\section{Seeding rate}

$\begin{array}{lcccccc}40 \mathrm{gm}^{-2} & 10.3 & 8.7 & 118.4 & 29.8 & 3.73 & 7.06 \\ 25 \mathrm{gm}^{-2} & 10.9 & 9.2 & 121.9 & 29.9 & 4.04 & 7.88 \\ \text { LSD }_{0.05} & 0.3 & 0.4 & 2.2 & \mathrm{~ns} & 0.19 & 0.48\end{array}$

311

312

313

Nutrient management $\left(\mathrm{N}-\mathrm{P}_{2} \mathrm{O}_{5}-\mathrm{K}_{2} \mathrm{O} \mathrm{kgha}^{-1}+5 \mathrm{ha}^{-1} \mathrm{FYM}\right)$

$\begin{array}{lcccccc}25-0-0 & 9.7 & 8.0 & 113.3 & 29.9 & 3.45 & 6.84 \\ 50-30-15 & 11.8 & 10.2 & 130.1 & 29.9 & 4.57 & 8.61 \\ 25-30-15 & 10.8 & 9.3 & 121.1 & 29.8 & 3.96 & 7.22 \\ 0-30-15 & 10.1 & 8.4 & 116.0 & 29.8 & 3.56 & 7.21 \\ \text { LSD }_{0.05} & 0.3 & 0.3 & 2.0 & \text { ns } & 0.24 & 0.59\end{array}$

${ }^{*}$ ns $=$ not significant 25-d-old seedlings (Table 4). Grain and straw yields increased by $8.3 \%$ and $11.6 \%$, respectively, under low nursery seeding rate; and were significantly higher with the application of 50-30-15 kg N-P $\mathrm{P}_{2}-\mathrm{K}_{2} \mathrm{O} \mathrm{ha}^{-1}$ than other nursery nutrient management treatments. However, all interactions were not significant. 
319 The cost of production increased by US $\$ 10 \mathrm{ha}^{-1}$ when higher seeding rate was used in 320 the nursery (Table 5), $\$ 20 \mathrm{ha}^{-1}$ when transplanting younger seedlings, and by $\$ 6 \mathrm{ha}^{-1}$ with 321 application of 50-30-15 kg N-P $\mathrm{P}_{2} \mathrm{O}_{5}-\mathrm{K}_{2} \mathrm{O}$ ha $^{-1}$, compared with 25-0-0 kg N-P $\mathrm{O}_{5}-\mathrm{K}_{2} \mathrm{O}$ ha ${ }^{-1}$.

322 Gross return increased by $21 \%$ when a lower seeding rate was used in the nursery. The

323 highest gross return $\left(\$ 1,251 \mathrm{ha}^{-1}\right)$ was observed when applying 50-30-15 kg N- $\mathrm{P}_{2} \mathrm{O}_{5}-\mathrm{K}_{2} \mathrm{O} \mathrm{ha}^{-1}$

324 to the nursery, and the lowest $\left(\$ 947 \mathrm{ha}^{-1}\right)$ with $25-0-0 \mathrm{~kg} \mathrm{~N}-\mathrm{P}_{2} \mathrm{O}_{5}-\mathrm{K}_{2} \mathrm{O} \mathrm{ha}^{-1}$, which was at par 325 with the application of 0-30-15 $\mathrm{kg} \mathrm{N}-\mathrm{P}_{2} \mathrm{O}_{5}-\mathrm{K}_{2} \mathrm{O}$ ha ${ }^{-1}$. The gross margin was $\$ 222 \mathrm{ha}^{-1}$ higher 326 when transplanting 40-d-old seedlings than with using 25 -d-old seedlings. The gain was 327 higher (gross margin increase by $26.8 \%$ ) when transplanting seedlings produced using lower 328 seeding rate. The gross margin was also significantly influenced by nursery nutrient 329 management, being highest for the use of 50-30-15 kg N-P $\mathrm{O}_{5}-\mathrm{K}_{2} \mathrm{O} \mathrm{ha}^{-1}$ followed by 25-30$33015 \mathrm{~kg} \mathrm{~N}-\mathrm{P}_{2} \mathrm{O}_{5}-\mathrm{K}_{2} \mathrm{O}$ ha ${ }^{-1}$ and the lowest with $25-0-0 \mathrm{~kg} \mathrm{~N}-\mathrm{P}_{2} \mathrm{O}_{5}-\mathrm{K}_{2} \mathrm{O}$ ha ${ }^{-1}$.. Consequently, the 331 highest BCRs of 1.82, 1.72, and 1.91 were observed when transplanting 40-d-old seedlings, 332 using a seed density of $25 \mathrm{~g} \mathrm{~m}^{-2}$, and applying 50-30-15 $\mathrm{kg} \mathrm{N}-\mathrm{P}_{2} \mathrm{O}_{5}-\mathrm{K}_{2} \mathrm{O}$ ha $^{-1}$, respectively. 333 However, all interactions of seed rate, nutrient options, and seedling age were not significant 334 for all parameters included in the economic analyses.

335

336

Table 5

337 Economic analyses (US\$ ha ${ }^{-1}$ ) of nursery management practices in the on-station experiment 338 at CSSRI-RRS, Canning Town, averaged over 2011 and 2012 wet seasons. 339

\begin{tabular}{lcccc}
\hline & $\begin{array}{c}\text { Cost of } \\
\text { cultivation }\end{array}$ & $\begin{array}{c}\text { Gross } \\
\text { return }\end{array}$ & $\begin{array}{c}\text { Gross } \\
\text { margin }\end{array}$ & BCR \\
\hline Age of seeding & & & & \\
40-d & 643 & 1165 & 524 & 1.82 \\
25-d & 664 & 965 & 302 & 1.45 \\
LSD $_{0.05}$ & 0.2 & 84 & 84 & 0.13
\end{tabular}




\section{Seed density}

$40 \mathrm{~g} \mathrm{~m}^{-2}$

$25 \mathrm{~g} \mathrm{~m}^{-2}$

$\mathrm{LSD}_{0.05}$

658

648

1022

1109

364

0.1

46

$461 \quad 1.72$

Nutrient management $\left(\mathrm{N}-\mathrm{P}_{2} \mathrm{O}_{5}-\mathrm{K}_{2} \mathrm{O} \mathrm{kg} \mathrm{ha}{ }^{-1}+5 \mathrm{tha}^{-1} \mathrm{FYM}\right)$

25-0-0

50-30-15

25-30-15

649

655

654

$947 \quad 299$

$1251 \quad 596$

596

1.47

0-30-15

653

$1081 \quad 427$

$\mathrm{LSD}_{0.05}$

0.3

$981 \quad 328$

1.91

1.66

340

341

342

3.2. On-farm evaluation of improved nursery management

343

The highest mean SVI $(5,423)$ was observed with improved nursery management and

344 improved stress-tolerant varieties Amal-Mana and Swarna-Sub1, and the lowest SVI $(3,675)$

345 was with farmers' variety and nursery management (Fig. 3). Use of an improved variety with

346 farmers' practices had an SVI of 4,824, indicating that replacing current farmers' varieties

347 alone will result in substantial improvements in seedling vigour and, subsequently, in crop

348 establishment in coastal saline areas. The mean SVI values with farmer's nursery

349 management and improved nursery management were, respectively, $23 \%$ and $21 \%$ higher for

350 Amal-Mana than for Swarna-Sub1, resulting in better performance of Amal-Mana in fields

351 affected by stagnant floods.

352 


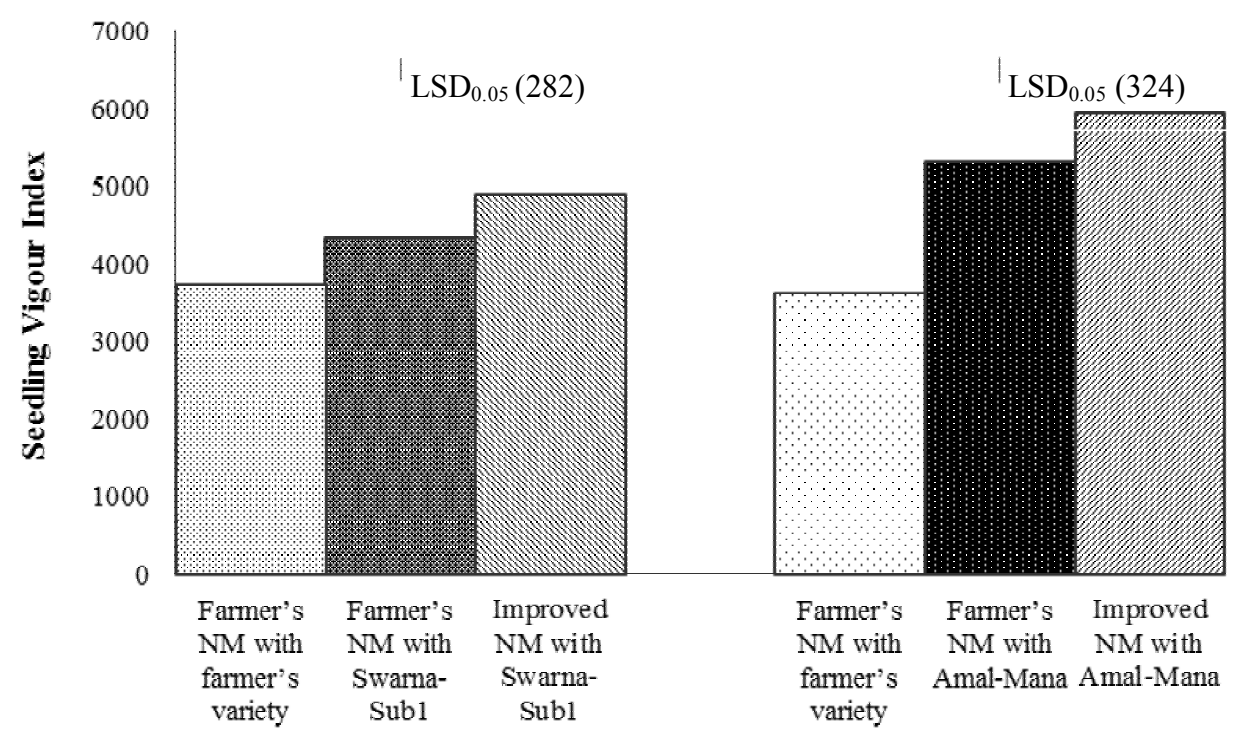

354 Fig. 3. Seedling Vigour Index as influenced by nursery management practices. Data are means of the 2012 and 2013 wet seasons. Vertical bars indicate LSD at $P \leq 0.05$ for treatment means. $\mathrm{NM}=$ nursery management. improved variety was $3.88 \mathrm{t} \mathrm{ha}^{-1}$, which is $36.6 \%$ higher than farmer's nursery management and farmer's variety, and $10.2 \%$ higher than farmer's nursery management and improved variety (Fig. 4a). The yield advantages of Swarna-Sub1 and Amal-Mana with improved nursery management were $23 \%$ and $47 \%$ higher than from farmer's nursery management and farmer's variety, respectively. Swarna-Sub1 performed better than Pratikshya and Sabita in areas affected by flash floods, whereas the taller variety Amal-Mana performed well in fields affected by stagnant flooding, out-yielding CR1017, Pankaj, and Mahsuri, which are traditionally grown in the coastal areas of West Bengal. Similarly, the straw yields (Fig. 4b) increased significantly with improved varieties and nursery management $\left(7.09 \mathrm{t} \mathrm{ha}^{-1}\right)$ as compared with improved varieties and farmer's nursery management $\left(6.58 \mathrm{tha}^{-1}\right)$ or with both farmer's varieties and nursery management $\left(5.28 \mathrm{t} \mathrm{ha}^{-1}\right)$. 

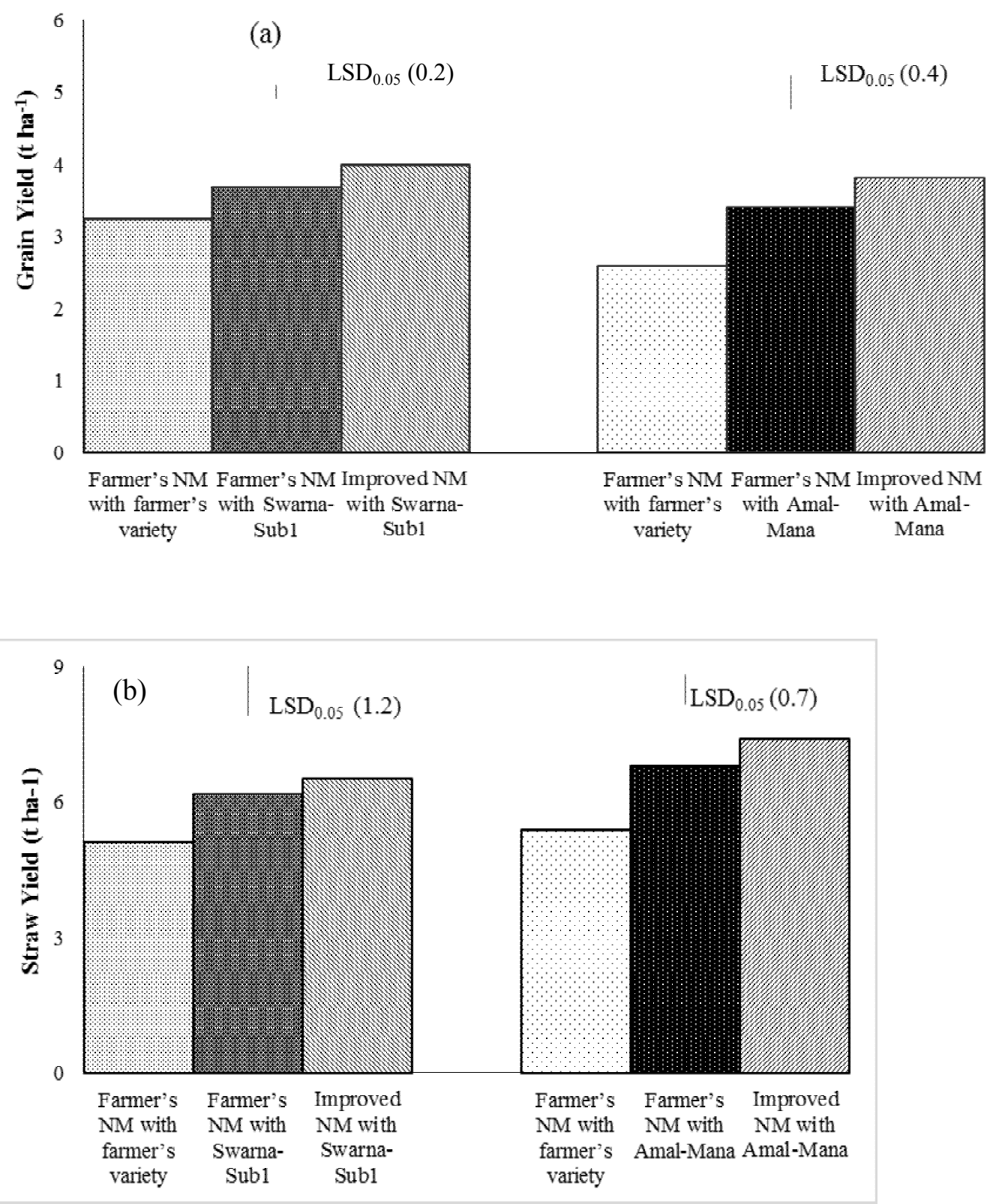

373 Fig. 4. (a) Grain and (b) straw yields as influenced by nursery nutrient management practices

374 in on-farm trials. Data are means of the wet seasons of 2012 and 2013. Vertical bars indicate

375 LSD at $P \leq 0.05$ for treatment means. NM= nursery management.

4. Discussion

Knowledge about the best agricultural practices that favor the expression of tolerance

379 of abiotic stresses of the new tolerant varieties are presently inadequate. This study is an 
attempt to develop a set of improved management practices for rainfed lowland stress tolerant rice grown in salt and flood affected coastal areas.

\subsection{Effects of seed density and seedling age on seedling growth and crop performance}

Seeding density in the nursery significantly affected seedling vigour. Seedling

biomass, shoot and root length, number of green leaves per seedling, leaf area, and leaf $\mathrm{N}$ concentration significantly improved when the lower seed rate of $25 \mathrm{~g} \mathrm{~m}^{-2}$ was used (Table 3). Providing more space for seedlings in the nursery enhanced seedling growth, probably enhancing light interception, and nutrient and moisture uptake. Lal and Roy (1996) reported that low seeding density of $50 \mathrm{~g} \mathrm{~m}^{-2}$ in the nursery produced significantly taller plants with more leaves as compared with 75 and $100 \mathrm{~g} \mathrm{~m}^{-2}$ seeding rate. Ram et al. (2009) reported that

390 lower seed density in the nursery $\left(50 \mathrm{~g} \mathrm{~m}^{-2}\right.$ compared to $\left.100 \mathrm{~g} \mathrm{~m}^{-2}\right)$ produced vigorous

391 seedlings with higher shoot biomass and shoot carbohydrate content. High concentrations of

392 non-structural carbohydrates in stems are known to be associated with higher tolerance of

393 flooding and early recovery in rice (Das et al., 2009; Singh et al., 2014; Kato et al., 2014).

394 Reduction of seed density to $25 \mathrm{~g} \mathrm{~m}^{-2}$ will therefore, improve seedling root growth, which could result in better nutrient uptake and seedling growth.

Seedlings produced with wider spacing established faster after transplanting, had

397 better survival after 10 to $15 \mathrm{~d}$ of complete submergence, and showed better recovery

398 following submergence (Ram et al., 2009). In this study, sowing Amal-Mana, at nursery

399 seed rate of $25 \mathrm{~g} \mathrm{~m}^{-2}$ resulted in $6 \%$ more panicles hill ${ }^{-1}$ and $3 \%$ more grains panicle ${ }^{-1}$,

400 leading to $8 \%$ and $12 \%$ higher grain and straw yields, respectively. A similar study by

401 Sumon et al. (2013) also demonstrated beneficial effects of healthy and more robust

402 seedlings produced from lower seed density in the nursery. They observed that the lower

403 seeding rate of $25 \mathrm{~g} \mathrm{~m}^{-2}$ produced 7-21\% higher grain yields in BRRI dhan51 as compared

404 with a seeding rate of $40 \mathrm{~g} \mathrm{~m}^{2}$. Mustari et al. (2013) found that seedlings from nurseries with 
405 low seeding density $\left(25 \mathrm{~g} \mathrm{~m}^{-2}\right.$ versus $\left.40 \mathrm{~g} \mathrm{~m}^{-2}\right)$ were more vigorous and had a yield

406 advantage ranging from $29 \%$ to $141 \%$ for different varieties and submergence conditions,

407 with greater response in tall, submergence-intolerant varieties such as Mahsuri. Better stress

408 tolerance and higher yields due to healthy and vigorous seedlings were also reported by

409 TeKrony and Egli (1991), Ella and Ismail (2006), Singh et al. (2012), and Adhikari et al.

410 (2013).

$411 \quad$ Optimal transplanting age is dependent on field conditions at transplanting; with

412 younger seedlings favored when conditions are ideal and hydrology is well controlled, as in

413 irrigated ecosystems. Contrary to this notion, our data showed that growth of 40-d-old

414 seedlings was significantly better than that of 25 -d-old seedlings in these less favorable areas.

415 This was reflected in better shoot biomass (134\%), shoot length (35\%), root length (27\%),

416 number of green leaves per seedling (13\%), and leaf area (8\%). Transplanting 40-d-old

417 seedlings also increased panicles per hill and grains per panicle, leading to a $22 \%$ higher

418 grain yield. Older seedlings were taller, sturdier and healthier; as a result, they could cope

419 better with deeper water prevalent in coastal rainfed, low-lying areas. Transplanting of $8 \mathrm{~d}$ to

$42012 \mathrm{~d}$ old seedlings as recommended in the System of Rice Intensification (Stoop et al., 2002)

421 for favorable areas is therefore not adequate in systems without water control, un-leveled

422 fields, and sub-optimal soil conditions. Taller seedlings are necessary to keep sufficient

423 portion of the plant above the floodwater.

424 However, there are trade-offs when seedlings stay too long in the nursery. The

425 primary tiller buds on the lower nodes of the main culm often degenerate (Mobasser et al.,

426 2007), resulting in reduced tillering after transplanting. The same authors reported that

427 number of panicles per $\mathrm{m}^{2}$ was highest with 45-d-old seedlings; but grain yield was higher

428 when transplanting 35-d-old seedlings. Similarly, Amin and Haque (2009) reported that 35-d-

429 old seedlings were better than younger (15- and 25-d-old) or older (45-d-old) ones. The better 
430 performance of older seedlings (35- to 45- d-old as compared with 25- to 30-d-old) was also

431 reported by Channabasappa et al. (1998), Alam et al. (2002), Ella and Ismail (2006),

432 Adhikari et al. (2013), Sumon et al. (2013), and Bhowmick et al. (2014) in less favorable

433 conditions. Older seedlings had higher dry biomass and carbohydrate storage at transplanting.

434 Consequently, they were more tolerant of submergence and waterlogging in the field (Ella

435 and Ismail, 2006; Bhowmick et al., 2014). Also, older seedlings are less sensitive to salinity

436 (Ram et al., 2009) and farmers often transplant older seedlings ( $>40 \mathrm{~d}$ ) if rainfall is delayed

437 (Subedi, 2013).

438

439

4.2. Effects of nursery nutrient management on seedling growth and crop performance

440

Applying fertilizers in the seedbed had several advantages. In the relatively small area

441 of the nursery, even small amounts of fertilizers can make a difference, and healthier

442 seedlings cope better with the transplanting 'shock' and perform better when conditions are

443 suboptimal. And fertilizer use in the small area of the seedbed is more affordable for

444 resource-limited. In this study, the application of inorganic and organic fertilizers (50-30-15

$445 \mathrm{~kg} \mathrm{~N}-\mathrm{P}_{2} \mathrm{O}_{5}-\mathrm{K}_{2} \mathrm{O} \mathrm{ha}^{-1}+5 \mathrm{t} \mathrm{FYM} \mathrm{ha}^{-1}$ ) in the seedbed resulted in better seedling growth, higher

446 leaf nitrogen concentration, and higher grain yield in the main field (Table 4). Ros et al.

447 (2003) as well as Sharma and Ghosh (1999) concluded that the response of rice yield to

448 improved nursery nutrition is largely due to increased seedling vigour and the increase in

449 seedling nitrogen concentration. Higher leaf $\mathrm{N}$ concentration in rice seedlings improved

450 growth of leaf and root apices immediately after transplanting and hastened recovery.

451 Enriching nursery seedbeds with N, P and Zn along with FYM, improved seedling vigour

452 relative to the unfertilized control and resulted in 10-30\% higher shoot carbohydrate

453 concentration before transplanting (Ram et al., 2009). The nutritional status of seedlings just

454 before transplanting can be of immense importance, especially when plants are subjected to 
455

456

457

458

459

460

461

462

463

464

465

466

467

468

469

470

471

472

473

474

475

476

477

478

submergence during early growth stages. Farmers' practice of applying only $\mathrm{N}$ fertilizers in the nursery to produce taller and greener seedlings may not have a positive effect in floodprone areas because high $\mathrm{N}$ content in transplanted seedlings reduces survival and recovery growth (Ella and Ismail, 2006). However, when N is applied with P (Jackson and Ram, 2003;

Gautam et al., 2014) and micronutrients such as Zn (Ella and Ismail, 2006), it improves seedling vigour and enhances tolerance to abiotic stresses. The beneficial effects of higher application of $\mathrm{N}, \mathrm{P}$, and $\mathrm{Zn}$ in the nursery (up to twice the recommended dose of 48-44-11 $\mathrm{kg}$ $\mathrm{N}-\mathrm{P}_{2} \mathrm{O}_{5}-\mathrm{ZnO}$ ha $^{-1}$ ), along with $10 \mathrm{t} \mathrm{ha}^{-1} \mathrm{FYM}$, was also demonstrated in gypsum-amended sodic soils (Yaduvanshi and Sharma, 2012). Ella and Ismail (2006) observed poorer plant survival if high $\mathrm{N}$ was applied just before transplanting compared with early $\mathrm{N}$ application, irrespective of the genotypes' tolerance level. Application of $\mathrm{P}$, either alone or together with $\mathrm{N}$, improved the survival of plants in P-deficient soils after $12 \mathrm{~d}$ of complete submergence. Thus, adequate nursery fertilizer rate and type depend on various factors such as initial soil fertility, application of organic nutrient sources, genotype tolerance of anticipated stresses, seeding rate in the nursery, and abiotic stresses in the field after transplanting. For transplanted rainfed lowland rice in the mid-hills of Nepal, the recommended $\mathrm{N}$ rate for the nursery is $30 \mathrm{~kg} \mathrm{ha}^{-1}$ (Subedi, 2013). Experiments by Panda et al. (1991) showed that grain yield increased by $20 \%$ with the $\mathrm{N}$ rate increase from 0 to $100 \mathrm{~kg} \mathrm{~N} \mathrm{ha}^{-1}$ in the rice nursery before transplanting. No significant effect of increasing the nursery $\mathrm{N}$ dose from $60 \mathrm{~kg}$ to 120 $\mathrm{kg} \mathrm{ha}^{-1}$ was reported by Singh (1999) at Kharagpur in West Bengal. Our results did confirm beneficial effects of balanced nursery fertilizer rates at low to medium levels at the study sites (Table 4 and 5). And adding organic sources such as FYM not only supplies macro nutrients but also essential micronutrients such as $\mathrm{S}, \mathrm{Fe}, \mathrm{Mn}, \mathrm{Cu}$, and $\mathrm{Zn}$ (Maskina et al., 1985). 

conditions

Improved rice varieties are a key component for high and stable yields in rainfed delta environments. But their suitability depends on several factors, including input requirements and response, growth behavior and adaptation to prevailing biotic and abiotic stresses (Alam et al., 2012). New varieties such as Swarna-Sub1 and Amal-Mana outperformed the current farmers' varieties, mainly because of their better tolerance to complete submergence and stagnant floods. Swarna-Sub1 is submergence-tolerant and can 487 produce 1.0 to $3.5 \mathrm{tha}^{-1}$ more grain yield than sensitive varieties, depending on the stage at which submergence occurred, the duration of submergence, and the conditions of the floodwater (Das et al., 2009; Sarkar et al., 2009; Ismail et al., 2013). In the on-farm study conducted during the wet season of 2012 and 2013, varieties traditionally grown by farmers

491 performed poor when flash-flooding occurred. At these sites, Swarna-Sub1 showed a yield 492 advantage of up to $0.82 \mathrm{tha}^{-1}$, with an average of $0.75 \mathrm{t} \mathrm{ha}^{-1}$. Similarly, Amal-Mana had an 493 average yield advantage of $1.22 \mathrm{tha}^{-1}$ (range of 0.87 to $2.22 \mathrm{t} \mathrm{ha}^{-1}$ ) across the five sites 494 where stagnant flooding was experienced during most of the season (Fig. 1). However, 495 Swarna-Sub1 is not adapted to long-term stagnant flooding prevalent in low-lying areas in 496 the coastal zones (Singh et al., 2011; Vergara et al., 2014). In such conditions, the tall, salt497 tolerant variety Amal-Mana outperformed traditionally grown varieties because of its ability 498 to partially elongate under stagnant floods.

499 Our results indicated that replacing current farmers' varieties could improve rice 500 production in coastal saline areas. But combining an improved variety with improved 501 management resulted in higher yields and revenues. Improved management practices could 502 also improve yield of the current farmers' varieties, but this was not evaluated in this study, 503 given the urge for farmers to replace their existent varieties with stress tolerant ones. The 
504 mean grain yield with improved nursery management and improved variety was 37\% higher

505 than farmer's practice, and 10\% higher than farmer's nursery management and improved

506 variety. Purushottam et al. (2012) found that grain yield in a rice-wheat system did only

507 significantly increase when improved varieties were combined with improved crop

508 establishment methods. Grain yield and economic gains were further enhanced when

509 balanced fertilizer was used. The mean benefit:cost (B:C) value of promising nursery

510 management combinations in our study was around 1.8 (Table 6). Reddy and Reddy (1992)

511 suggested that $\mathrm{B}: \mathrm{C}$ values $\geq 2$ are necessary for technology adoption but a benefit:cost ratio

512 above 1.5 has been considered economically viable for an agricultural enterprise, especially

513 when the investments are small (Makarim et al., 2002). Combining good nursery

514 management with high-yielding, stress-tolerant varieties could therefore improve system

515 productivity and farmers' income in tropical coastal zones, where abiotic stresses like flash

516 floods, stagnant flooding, and salinity are common.

517

518 5. Conclusions

519 This study showed that use of balanced nutrients and lower seeding rate in the nursery

520 produced healthier and more vigorous seedlings that withstood floods and salinity better

521 than seedlings produced through traditional farmers' practices. Good seedling vigour in the

522 nursery ensured faster recovery and growth and higher yield in the transplanted rice systems

523 when abiotic stresses are anticipated. The highest benefit:cost ratios were attained when

524 transplanting 40 -d-old seedlings produced using $25 \mathrm{~g}$ of seed per $\mathrm{m}^{2}$ and with application of

$52550-30-15 \mathrm{~kg} \mathrm{ha}^{-1} \mathrm{~N}-\mathrm{P}_{2} \mathrm{O}_{5}-\mathrm{K}_{2} \mathrm{O}+5 \mathrm{t} \mathrm{FYM} \mathrm{ha}^{-1}$, respectively. Application of a small amount

526 of nutrients at 5-3-1.5 kg N-P $2 \mathrm{O}_{5}-\mathrm{K}_{2} \mathrm{O}+500 \mathrm{~kg} \mathrm{FYM}$ in a nursery area of $1,000 \mathrm{~m}^{2}$, enough

527 to produce seedlings for 1 ha, can increase grain yields by up to $30 \%$ over current farmers'

528 practice. These cost-effective nursery management options have great potential to enhance 
529 yield in coastal areas affected by salt stress and could help cope with stagnant as well as

530 flash flood incidences. The results of this study can effectively be recommended for rainfed

531 lowlands of West Bengal and for other areas in adjoining coastal states of India,

532 Bangladesh, Vietnam, and Myanmar that have similar ecologies.

533

534 Acknowledgments

535 The authors are grateful to the European Commission (EC), the International Fund for 536 Agricultural Development (IFAD), and the Bill \& Melinda Gates Foundation for funding this 537 research through grants to the International Rice Research Institute. We greatly acknowledge 538 the encouragement and support of the Director of the Central Soil Salinity Research Institute, 539 Karnal, Haryana, India, and for providing the necessary facilities for this study. 540 


\section{References}

541 Abdul-Baki, A.A., Anderson, J.D., 1973.Vigor determination in soybean seed by multiple criteria.

542 Crop Sci. 13, 630-633.

543 Adhikari, B.B., Mehera, B., Haefele, S.M., 2013. Impact of rice nursery nutrient management,

544 seeding density and seedling age on yield and yield attributes. American J. Plant Sci. 4, 146-155.

545 Alam, M.S., Baki, M.A., Sultana, M.S., Ali, K.J., Islam. M.S., 2012. Effect of variety, spacing and

546 number of seedlings per hill on the yield potentials of transplant aman rice. Int. J. Agron. Agric.

$547 \quad$ Res. 2, 10-15.

548 Alam, M.Z., Ahmed, M., Alam, M.S., Haque, M.E., Hossin, M.S., 2002.Performance of seedling ages

549 and seedling raising techniques on yield and yield components of transplant Aman rice. Pakistan

$550 \quad$ J. Biol. Sci. 5, 1214-1216.

551 Amin, A.K.M.K., Haque, M.A., 2009. Seedling age influence rice (Oryza sativa L.) performance.

$552 \quad$ Philippine J. Sci. 138, 219-226.

553 Bhowmick, M.K., Dhara, M.C., Singh, S., Dar, M.H., Singh, U.S., 2014. Improved management

554 options for submergence-tolerant (Sub 1) rice genotypes in flood-prone rainfed lowlands of West

555 Bengal. American J. Plant Sci. 5, 14-23.

556 Channabasappa, K.S., Reddy, B.G.M., Patil, S.G. Deneshkumar, M., 1998. Response of late

557 transplanted rice (Oryza sativa) to age, number of seedlings and fertilizer levels. Indian J. Agron.

$558 \quad 43,636-638$.

559 Das, K.K., Panda, D., Sarkar, R.K., Reddy, J.N., Ismail, A.M., 2009. Submergence tolerance in

560 relation to variable floodwater conditions in rice. Environ. Exp. Bot. 66, 425-434.

561 Das, S.R., 2012. Rice in Odisha. IRRI Technical Bulletin No. 16. International Rice Research

562 Institute, Los Baños, Philippines. 31 p.

563 Ella, E.S., Ismail, A.M., 2006. Seedling nutrient status before submergence affects survival after

564 submergence in rice. Crop Sci. 46, 1673-1681. 
Ella, E.S., Dionisio-Sese, M.L., Ismail, A.M., 2011. Application of silica before sowing negatively affects growth and survival of rice following submergence. Philippine J. Crop Sci. 36, 1-11.

567 Gautam, P., Nayak, A.K., Lal, B., Bhattacharyya, P., Tripathi, R., Shahid, M., Mohanty, S., Raja, R., Panda, B.B., 2014. Submergence tolerance in relation to application time of nitrogen and phosphorus in rice (Oryza sativa L.). Environ. Exp. Bot. 99, 159-166.

Gomez, K.A., Gomez, A.A., 1984. Statistical procedures for agricultural research. John Wiley and

Ismail, A. M., Tuong T. P. 2009. Brackish water coastal zones of the monsoon tropics: challenges and opportunities. In: Haefele, S.M., Ismail, A.M. (Eds.), Natural Resource Management for Poverty Reduction and Environmental Sustainability in Fragile Rice-based Systems. Proceedings No.15. International Rice Research Institute, Los Baños, Laguna, Philippines, pp. 113-121.

Ismail, A.M., Johnson, D.E., Ella, E.S., Vergara, G.V., Baltazar, A.M., 2012. Adaptation to flooding during emergence and seedling growth in rice and weeds, and implications for crop establishment. AoB PLANTS: Pls019; doi:10.1093/aobpla/pls019.

Ismail, A.M., Singh, U.S., Singh, S., Dar, M.H., Mackill, D.J., 2013. The contribution of submergence-tolerant (Sub1) rice varieties to food security in flood-prone rainfed lowland areas in Asia. Field Crops Res.152, 83-93.

Jackson, M.B., Ram, P.C., 2003. Physiological and molecular basis of susceptibility and tolerance of rice plants to complete submergence. Ann. Bot. 91, 227-241.

Kato Y, Collard BCY, Septiningsih EM, Ismail AM. 2014. Physiological analyses of traits associated with tolerance of long-term partial submergence in rice. AoB PLANTS 6: plu058; doi:

10.1093/aobpla/plu058

Lal, M., Roy, R.K., 1996. Effect of nursery seeding density and fertilizer on seedling growth and yield of rice (Oryza sativa). Indian J. Agron. 41, 642-644.

Mackill, D. J., Ismail, A. M., Singh, U. S., Labios, R. V., Paris, T. R., 2012. Development and rapid adoption of submergence-tolerant (Sub1) rice varieties. Adv. Agron. 115, 299-352.

Makarim, A.K., Balasubramanian, V., Zaini, Z., Syamsiah, I., Diratmadja, I.G.P.A. Handoko, A., 2002. Systems of rice intensification (SRI): evaluation of seedling age and selected components 
in Indonesia, In: Bouman, B.A.MA., Hengsdijk, H., Hardy, B., Bindraban, P.S., Tuong, T.P., 594 Ladha, J.K. (Eds), International Workshop on Water-wise Rice Production, Los Baños, 8-11

595 April 2002, International Rice Research Institute, Philippines, pp. 129-139.

596

597

598

599

600

601

602

603

604

605

606

607

608

609

610

611

612

613

614

615

616

Maskina, M.S., Sandhu, P.S., Meelu, O.P., 1985. Effect of integrated use of organic and inorganic nitrogen sources on growth and nutrient composition of rice seedlings. Oryza 22, 11-16.

Mobasser, H.R., Tari, D.B., Muhammad, V., Abadi, R.S., Ali, E., 2007. Effect of seedling age and planting space on yield and yield components of rice (Neda variety). Asian J. Plant Sci. 6, 438440.

Mustari, S., Hossain, M.S., Islam, M.S., Salam, M.A., Kader, M.A., 2013. Performance of BRRI hybrid dhan 4 as influenced by seed rate in nursery bed and age of seedling during transplanting. Eco-friendly Agric. J. 6, 160-163.

Panda, M.M., Reddy, M.D., Sharma, A.R., 1991. Yield performance of rainfed lowland rice as affected by nursery fertilization under conditions of intermediate deep water $(15-50 \mathrm{~cm})$ and flash floods. Plant Soil 132, 65-71.

Purushottam, K., Singh, D.K., Bhardwaj, A.K., 2012. On farm evaluation of agronomic management practices under rice-wheat cropping system. Extended summaries, Third International Agronomy Congress, New Delhi, pp. 1295-1296.

Ram, P.C., Mazid, M.A., Ismail, A.M., Singh, P.N., Singh, V.N., Haque, M.A., Singh, U., Ella, E.S., Singh, B.B., 2009. Crop and resource management in flood-prone areas: farmers' strategies and research development. In: Haefele, S.M., Ismail, A.M. (Eds), Natural Resource Management for Poverty Reduction and Environmental Sustainability in Fragile Rrice-Based Systems. Limited Proceedings No. 15. International Rice Research Institute, Los Baños, Philippines, pp. 82-94.

Reddy, K.S., Reddy, B.B., 1992. Effect of transplanting time, plant density and seedling age on growth and yield of rice. Indian J. Agron. 37, 18-21. 
617 Ros, C., Bell, R.W., White, P.F., 2003. Seedling vigour and the early growth of transplanted rice 618 (Oryza sativa). Plant Soil 252, 325-337.

619 Sarangi, S.K., Maji, B., Singh, S., Sharma, D.K., Burman, D., Mandal, S., Ismail, A.M., Haefele, 620 S.M., 2014. Crop establishment and nutrient management for dry season (boro) rice in coastal 621 areas. Agron. J. 106, 2013-2023.

622 Sarkar, R.K., Panda, D., Reddy, J.N., Patnaik, S.S.C., Mackill, D.J., Ismail, A.M., 2009. Performance 623 of submergence tolerant rice (Oryza sativa) genotypes carrying the Sub1 quantitative trait locus 624 under stressed and non-stressed natural filed conditions. Indian J. Agric. Sci. 79, 876-83.

625 Sarkar, R.K., Bhattacharjee, B., 2012. Rice genotype with SUB1 QTL differ in submergence

626 tolerance, elongation ability during submergence and re-generation growth at re-emergence. Rice $627 \quad 5,7-18$.

628 Sharma, A.R., Ghosh, A., 1999. Submergence tolerance and yield performance of lowland rice as 629 affected by agronomic management practices in eastern India. Field Crops Res. 63, 187-198.

630 Singh, S.K., 1999. Effect of nursery management techniques on nitrogen nutrition of rainfed, lowland 631 transplanted rice (Oryza sativa). Indian J. Agron. 44, 701-704.

632 Singh, S., Mackill, D.J., Ismail, A.M., 2009. Response of SUB1 rice introgression lines to 633 submergence in the field: yield and grain quality. Field Crops Res. 113, 12-23.

634 Singh, S., Mackill, D.J., Ismail, A.M., 2011. Tolerance of longer-term partial stagnant flooding is 635 independent of the SUB1 locus in rice. Field Crops Res. 121, 311-323.

636 Singh, S., Mackill, D.J., Ismail, A.M., 2014. Physiological bases of tolerance to complete

637 submergence in rice involves other genetic factors in addition to SUB1. AoB PLANTS6: plu060; 638 doi: 10:1093/aobpla/pluo60.

639 Singh, U.S., Dar, M.H., Singh, S., Zaidi, N.W., Bari, M.A., Mackill, D.J., Collard, B.C.Y., Singh, 640 V.N., Singh, J.P., Reddy, J.N., Singh, R.K., Ismail, A.M., 2013. Field performance, 641 dissemination, impact and tracking of submergence tolerant (Sub1) rice varieties in South Asia. 642 SABRAO J. Breed. Genet. 45, 112-131.

643 Singh, Y., Singh, U.P., Singh, S., Ravi Kumar, H.S., Sutaliya, J.M., Singh, U.S., Haefele, S.M., 2012. 644 Improved nursery management options for submergence tolerant (Sub1) rice genotypes in flood- 
prone environments. Extended summaries, Third International Agronomy Congress, New Delhi, 646 pp. $1248-1250$.

647 Stoop, W.A., Uphoff, N., Kassam, A., 2002. A review of agricultural research issues raised by the system of rice intensification (SRI) from Madagascar: opportunities for improving farming systems for resource-poor farmers. Agric. Syst. 71, 249-274.

Subedi, R., 2013. Nursery management influences yield and yield attributes of rainfed low land rice. J. Sustain. Soc. 2, 86-91.

Sumon, M., Bhuiya, M.S.U., Islam, M. S., Zaman, F., 2013. Effect of nursery management practices on growth and yield of BRRI dhan51 under submerged condition. J. Agrofor. Environ. 7, 85-88.

TeKrony, D.M., Egli, D.B., 1991. Relationship of seed vigor to crop yield: a review. Crop Sci. 31,

656 Varley, J.A., 1966. Automatic methods for the determination of nitrogen, phosphorus and potassium 657 in plant material. Analyst 91: 119-126.

658 Vergara, G.V., Nugraha, Y., Esguerra, M.Q., Mackill, D.J., Ismail, A.M., 2014. Variation in tolerance 659 of rice to long-term stagnant flooding that submerges most of the shoot will aid in breeding 660 tolerant cultivars. AoB PLANTS6: plu055; doi: 10.1093/aobpla/plu055.Wassmann, R., Jagadish, 661 S.V.K., Sumfleth, K., Pathak, H., Howell, G., Ismail, A., Serraj, R., Redona, E., Singh, R.K., 662 Heuer, S., 2009. Regional vulnerability of climate change impacts on Asian rice production and 663 scope for adaptation. Adv. Agron. 102, 91-133.

664 Yaduvanshi, N.P.S., Sharma, D.R., 2012. Maximizing of rice yield applied higher loading of 665 fertilizers at nursery stage. Extended summaries, Third International Agronomy Congress, New 666 Delhi, pp. 1241. 